\title{
CARBETOCIN VERSUS COMBINED OXYTOCIN AND METHERGINE FOR PREVENTION OF POSTPARTUM HEMORRHAGE AFTER VAGINAL DELIVERY IN HIGH RISK PREGNANCY
}

\author{
By

\section{Mohamed Gamal Nasr El-Shennawy, Mohamed Mohamed Gebreel and Alrefaai Abd El-Fattah Marai}

Department of Obstetrics and Gynecology, Faculty of Medicine, Al-Azhar University

Corresponding author: Mohamed Gamal Nasr El Shennawy,

E-mail: mohamedgamal5545@gmail.com

\begin{abstract}
Background: Around the world, one woman every minute dies as a result of postpartum hemorrhage (PPH) and it remains the single major cause of maternal mortality and morbidity. The early identification of risk factors and effective prevention and management of PPH are critical to minimize the impact of PPH. Carbetocin, a new drug for the prevention of uterine atony, is a synthetic analogue of oxytocin with a half-life of up to 4 to 10 times longer than that of oxytocin. In comparison with oxytocin, it is used as a single-dose injection instead of an infusion and can be given intravenously or intramuscularly.

Objective: To evaluate the effect of carbetocin in preventing postpartum hemorrhage after vaginal delivery in comparison with combined oxytocin and methergine.

Patients and methods: This study was conducted at Al-Galaa Maternity Hospital during the period from 1 June to 1 December 2020. The study included 100 candidates between 37 to 40 weeks with a risk factor to develop PPH divided randomly into two equal groups: Group A received a single $100 \mathrm{mg}$ IM dose of carbetocin $\left(\mathrm{Pabal}^{\circledR}\right.$ ) and Group B received 5 IU IM oxytocin (Syntocinon ${ }^{\circledR}$ ) combined with $1 \mathrm{~mL}, 0.2 \mathrm{mg} \mathrm{IM}$ methylergonovine maleate (Methergine ${ }^{\mathbb{R}}$ ).

Results: Carbetocin was more effective, with significant difference, in reducing the time of 3rd stage of labor, reducing amount of blood loss and drop of both $\mathrm{HB} \%$ and hematocrit levels with significant decreased incidence of side effects.

Conclusion: A single $100 \mathrm{mg}$ IM dose of carbetocin $\left(\mathrm{Pabal}^{\circledR}\right)$ may be more effective as compared to $5 \mathrm{IU}$ IM oxytocin (Syntocinon ${ }^{\circledR}$ ) combined with $1 \mathrm{~mL}, 0.2 \mathrm{mg}$ IM methylergonovine maleate (Methergine ${ }^{\circledR}$ ) in reducing postpartum blood loss with a smaller drop in hemoglobin levels.
\end{abstract}

Keywords: Carbetocin, Combined Oxytocin and Methergine, Postpartum Hemorrhage, Vaginal Delivery.

\section{INTRODUCTION}

Postpartum hemorrhage ( $\mathrm{PPH})$ is defined as a blood loss more than $500 \mathrm{ml}$ and serious PPH as a blood loss more than $1,000 \mathrm{ml}$. PPH is a serious condition remaining the single main cause of maternal morbidity and mortality $(\mathrm{Su}$ et al., 2012).

The risk of postpartum complications in women who received a caesarean section (CS) was higher than that in women who underwent a vaginal delivery 
(VD) and vaginal birth after cesarean section (VBAC). The incidence of $\mathrm{PPH}$ has been reported to be $3.9 \%$ in women delivered vaginally and reaches $7.9 \%$ after CS. The Millennium Development Goal of reducing the maternal mortality ratio by $75 \%$ by 2015 will remain beyond our reach unless we prioritize the prevention and treatment of PPH in low-resource countries (Edhi et al., 2013 and Maged et al., 2016).

Currently, oxytocin is the uterotonic of first choice for the Active Management of Third Stage Labor (AMTSL), recommended by WHO to prevent postpartum blood loss. Prophylactic use of oxytocin after delivery of the infant has been shown to reduce the incidence of PPH by about $60 \%$. Oxytocin has a halflife of only 4-10 min that is why it is better administered as a continuous intravenous infusion to achieve sustained uterotonic activity. Carbetocin is a synthetic long-lasting oxytocin agonistic analog with prolonged half-life. Its prolonged uterine activity may theoretically offer advantages over oxytocin in the management of the third stage of labor (Westhoff et al., 2013).

Carbetocin is superior to oxytocin in prevention of PPH after VD in women with at least two risk factors for developing atonic PPH. The side-effect profile of carbetocin was not found to be different from that of oxytocin (Maged et al., 2016).

Carbetocin is a synthetic long-lasting oxytocin agonistic analogue with prolonged half-life prolonging its pharmacological effects. Its prolonged uterine activity may theoretically offer advantages over oxytocin in the management of the third stage of labor. The side-effect profile of carbetocin was not found to be different from that of oxytocin, but may prove to be advantageous when compared to Syntometrine (Grotegut et al., 2011).

Ergometrine is a selective and moderately potent tryptaminergic receptor antagonist in various smooth muscles, being only a partially agonistic or antagonistic at tryptaminergic receptors in the central nervous system. In blood vessels, the alkaloid is only weakly antagonistic of dopaminergic receptors and partially agonistic of $\alpha$-adrenergic receptors (Zein El Abdeen, 2018).

A study investigated the efficacy of carbetocin vs. oxytocin for prevention of uterine atony in high-risk women undergoing delivery by caesarean section. Significantly, fewer women experienced uterine atony after caesarean delivery with carbetocin (8\%) vs. oxytocin (19\%). Blood loss $>500 \mathrm{ml}$ was only observed in women who received oxytocin (El Behery et al., 2016).

The aim of our study was to compare between the efficacy of using carebtocin or combined oxytocin a methergine in preventing postpartum hemorrhage following normal vaginal delivery in high risk patients.

\section{PATIENTS AND METHODS}

This study was conducted at Al-Galaa Maternity Teaching Hospital during the period from 1 June to 1 December 2020. This study included 100 candidates between 37 and 40 weeks of gestation with risk factors for developing $\mathrm{PPH}$ divided into 2 equal groups: Group (1) (50 pregnant): were received a single dose of 
carbetocin $\left(\mathrm{Papal}^{\circledR}\right) 100 \mathrm{mg}$ I.M. Group (2) (50 pregnant): were received oxytocin (Syntocinon $^{\circledR}$ ) 5 I.U I.M combined with methylergonovine meleate (Methergine ${ }^{\circledR}$ ) $0.2 \mathrm{mg}$ I.M.

\section{Inclusion criteria:}

1. Women who expected to give birth vaginally.

2. $\mathrm{GA}=37-40$ weeks.

3. Women with risk factors for developing atonic $\mathrm{PPH}$ :

- Previous PPH.

- Primipara $>40$ years.

- Grandmultipara (> 5 previous vaginal deliveries.(

- $\quad$ BMI > 35.

- Multiple pregnancy.

- Prolonged labor.

- Ultrasound estimated fetal weight $>4 \mathrm{~kg}$.

\section{Exclusion criteria:}

1. GA: less than 37 weeks or more than 40 weeks.

2. Women with no risk factors for developing atonic PPH.

3. Women too distressed to provide informed consent.

4. Women had known allergies to carbetocin, oxytocin homologues or methylergometrine.

5. Women had a serious cardiovascular disorder, serious hepatic or renal disease, epilepsy or coagulopathy.

6. Causes of antepartum hemorrhage such as: Placenta previa, abruptio placenta, .... etc.
All cases in the study are subjected to:

- Clinical evaluation including:

a. Complete history taking.

1. Personal history as regard name, age and address.

2. Menstrual history.

3. Obstetric history.

4. Drug history.

5. Past history of diabetes, hypertension, previous operation, blood transfusion and drug allergy, history of postpartum hemorrhage.

6. Family history of congenital anomalies, twins, diabetes and Hypertension.

\section{b. Examination.}

1. General examination:

- Vital signs (pulse, blood pressure, temperature).

- Head and neck examination.

- Chest and heart examination.

\section{- Abdominal examination:}

For assessment of fundal level, fetal lie and presentation, fetal heart sounds, uterine contractions, and scar of previous surgeries.

\section{- Lower limb examination.}

\section{- Local examination:}

After delivery to exclude traumatic postpartum hemorrhage, extension of episiotomy and to inspect placenta and membrane after separation. 


\section{Quantification of blood loss during vaginal Delivery:}

Quantification of maternal blood loss is a team effort.

1. A list of dry weights for delivery items that may become blood soaked with directions on how to calculate blood loss was created.

2. Quantification of blood loss immediately after the infant's birth (before delivery of the placenta) was begun and assessed and record the amount of fluid collected in a calibrated under-buttocks drape. Keep in mind that most of the fluid collected before delivery of the placenta is amniotic fluid, urine, and feces. If irrigation is used, subtract the amount of irrigation from the total fluid that callbrated under-buttocKs drape. Keep in mind that most of the fluid collected before delivery of the placenta is amniotic fluid, urine, and feces. If irrigation is used, subtract the amount of irrigation from the total fluid that was collected.

3. The total volume of fluid collected in the under-buttocks drape was recorded.

4. The preplacental fluid volume from the post placenta fluid volume to more accurately determine the actual blood loss was subtracted. Keep in mind that most of the fluid collected after the birth of the placenta is blood.

5. The fluid volume collected in the drapes to the blood volume measured by weighing soaked items to determine the cumulative volume of blood loss or quantification of blood loss was added.
6. All blood-soaked materials and clots to determine cumulative volume were weighed. Seven gram weight=J milliliter blood loss volume.

7. The equation used when calculating blood loss of a blood- soaked item was wET Item Gram weight - DRY Item Gram Weight=milliliters of Blood within the Item.

Although a gram is a unit of mass and a milliliter is a unit of volume, the conversion from one to the other is a simple 1-to-1 conversion.

Each group was comparable for maternal age, weight, height, body mass index and hematological values at entry, as well as for parity, gestational age and the use of cervical ripening, forceps delivery or epidural analgesia. All episiotomies if needed were performed mediolaterally throughout the study. If an oxytocin infusion was used during labor, it was stopped immediately at the end of second stage.

Fetal birth weight was recorded. Baseline blood pressure and pulse rate was recorded upon admission to the labor room. Blood samples were drawn to check for hemoglobin levels upon admission to the labor room and -repeated 2 hours and 12 hours after delivery. If uterine tone was not firm or the amount of bleeding was unsatisfactory after the administration of the drug, an additional oxytocic agent was administered. The time interval between initial selected drug administration and the type of additional oxytocic intervention was recorded. The umbilical cord was clamped immediately after delivery of the baby. The duration of the third stage was measured for detection of delayed placental separation, retained placenta or 
retained parts of placenta or membranes. Measurement of blood loss was started immediately after drug administration, where a new plastic sheet was placed under the patient's thighs following delivery of the baby in order to minimize the error of including amniotic fluid and blood absorbed into drapes .

The placenta was delivered via controlled cord traction. All gauzes, tampons and pads which were subsequently used were collected for the first hour following the delivery of the placenta. A digital weighing scale was used. The difference in weight of the material before and after the hour was calculated. A $100 \mathrm{gm}$ increase in weight was considered to be equivalent to 100 $\mathrm{mL}$ blood. Both assessment of the uterine fundal height after drug administration and the vital signs were monitored at 0,30 $\min$ and $60 \mathrm{~min}$ in the labor ward. An increase in systolic and diastolic pressures equal to or greater than 30 and $20 \mathrm{mmHg}$, respectively, were considered to be significant. The mean levels of blood pressures over the three post injection readings and the mean pulse rate for both groups at each set were calculated. The patients were monitored for side effects of the selected drug in the first 12 hours postdelivery.

Patients were questioned for side effects after drug administration, in the recovery room and in the post-natal ward. The patients were also monitored for signs of flushing, sweating, tremor and vomiting. Any other symptoms volunteered or signs observed by the attending doctor or nurse were also recorded. Any blood transfusion or iron sucrose injection postpartum or incidence of PPH was recorded in the first 12 hours post-delivery.

\section{Statistical Analysis:}

The analyses were carried with SPSS software (Statistical Package for the Social Sciences, version 24, SSPS Inc, Chicago, IL, USA). The normality of the data was assessed using Shapiro-Wilk Test. Numerical data were described as mean \pm SD if normally distributed. Frequency tables with percentages were used for categorical variables. Independent Student t-test and used to compare parametric quantitative variables. Chi-square test was used to analyze categorical variables. A p-value $<0.05$ was considered statistically significant.

\section{RESULTS}

As regards the demographic variables, the patients included $(n=100)$ in the study ranged in age from 18 to 39 years. The gestational age ranged from 37 to 41 weeks calculated from the first day of LMP. The gravidity ranged from 1 to 6 . There was no statistically significant difference between the two groups with regard to maternal age, gestational age, gravidity and parity. But regarding BMI, highly significant difference was observed between the two groups $(\mathrm{P}<0.05)$ (Table 1). 
Table (1): The demographic data of the patients

\begin{tabular}{|c|c|c|c|c|c|c|c|}
\hline Characteristics & Group & $\mathbf{N}$ & Mean & SD & Min. & Max. & P-value \\
\hline \multirow{3}{*}{ Age (years) } & Group 1 & 50 & 26.03 & 4.206 & 18 & 37 & \multirow{3}{*}{$>0.05$} \\
\hline & Group 2 & 50 & 27.27 & 6.362 & 18 & 39 & \\
\hline & Total & 100 & 26.65 & 5.383 & 18 & 39 & \\
\hline \multirow{3}{*}{ Gravidity } & Group 1 & 50 & 2.53 & 1.196 & 1 & 5 & \multirow{3}{*}{0.38} \\
\hline & Group 2 & 50 & 2.87 & 1.697 & 1 & 6 & \\
\hline & Total & 100 & 2.70 & 1.465 & 1 & 6 & \\
\hline \multirow{3}{*}{ GA (weeks) } & Group 1 & 50 & 39.23 & 0.898 & 37 & 41 & \multirow{3}{*}{$>0.05$} \\
\hline & Group 2 & 50 & 39.03 & 0.964 & 37 & 41 & \\
\hline & Total & 100 & 39.14 & 0.929 & 37 & 41 & \\
\hline \multirow{3}{*}{ Parity } & Group 1 & 50 & 1.23 & 1.135 & 0 & 4 & \multirow{3}{*}{0.36} \\
\hline & Group 2 & 50 & 1.53 & 1.408 & 0 & 4 & \\
\hline & Total & 100 & 1.38 & 1.277 & 0 & 4 & \\
\hline \multirow{3}{*}{ BMI } & Group 1 & 50 & 29.87 & 1.174 & 27.89 & 32.32 & \multirow{3}{*}{$<0.001$} \\
\hline & Group 2 & 50 & 29.01 & 1.217 & 25.86 & 31.60 & \\
\hline & Total & 100 & 29.44 & 1.263 & 25.86 & 32.32 & \\
\hline
\end{tabular}

N: number, SD: standard deviation, Min.: minimum, Max.: Maximum, GA: gestational age; BMI: Body Mass Index

Mann whitney u test

As regard to risk factors of $\mathrm{PPH}$ in group (1) \& (2), primipara $>40$ years was $42 \%$ \& $34 \%$, grand multipara $48 \%$ \& $52 \%$ and prolonged labour present in $10 \% \&$
$14 \%$ respectively with no statistical significant difference between both groups (Table 2).

Table (2): Comparison between groups as regard to risk factors of PPH.

\begin{tabular}{|c|c|c|c|c|c|}
\hline \multirow{2}{*}{ Risk of PPH } & \multicolumn{2}{|c|}{ Group (1) } & \multicolumn{2}{c|}{ Group (2) } & \multirow{2}{*}{ P-value } \\
\cline { 2 - 5 } & NO & \% & NO & \% & \\
\hline Primipara (> 40 years) & 21 & $42 \%$ & 17 & $34 \%$ & $>0.05$ \\
\hline Grand multipara & 24 & $48 \%$ & 26 & $52 \%$ & $>0.05$ \\
\hline Prolonged labour & 5 & $10 \%$ & 7 & $14 \%$ & $>0.05$ \\
\hline
\end{tabular}

$\mathrm{Hb} \%$, hematocrit value pre-delivery, 2 hours and 12 hours post-delivery, pulse rate pre-delivery, blood loss, fetal birth weight and time of 3rd stage among the studied groups. There is statistically significant difference regarding pre labor
HCT, 2hr post labor HCT, 12hr post labor HCT, time of 3rd stage of labor $(\mathrm{P}<$ $0.05)$, highly significant difference regarding blood loss $(\mathrm{P}<0.01)$ and nonsignificant difference regarding other items (Table 3). 
Table (3): Hb\%, hematocrit value predelivery, 2 hours and 12 hours postdelivery, pulse rate predelivery, blood loss, fetal birth weight and time of 3rd stage among the studied groups

\begin{tabular}{|c|c|c|c|c|c|c|c|}
\hline Characteristics & Group & $\mathbf{N}$ & Mean & SD & Min. & Max. & P-value \\
\hline \multirow{3}{*}{$\begin{array}{c}\text { Pre-labor } \\
\text { Pulse (bpm) }\end{array}$} & Group 1 & 50 & 78.03 & 5.974 & 67 & 90 & \multirow{3}{*}{$>0.05$} \\
\hline & Group 2 & 50 & 77.20 & 6.014 & 68 & 89 & \\
\hline & Total & 100 & 77.62 & 5.958 & 67 & 90 & \\
\hline \multirow{3}{*}{$\begin{array}{c}\text { Pre-labor } \\
\text { Hb\% (mg/dl) }\end{array}$} & Group 1 & 50 & 10.890 & 0.9455 & 9.5 & 12.7 & \multirow{3}{*}{$>0.05$} \\
\hline & Group 2 & 50 & 11.210 & 0.7517 & 9.7 & 12.5 & \\
\hline & Total & 100 & 11.050 & 0.8621 & 9.5 & 12.7 & \\
\hline \multirow{3}{*}{$\begin{array}{l}\text { Pre-labor } \\
\text { HCT }\end{array}$} & Group 1 & 50 & 31.200 & 2.1824 & 28.1 & 36.6 & \multirow{3}{*}{0.012} \\
\hline & Group 2 & 50 & 32.597 & 3.1601 & 26.3 & 38.8 & \\
\hline & Total & 100 & 31.898 & 2.7831 & 26.3 & 38.8 & \\
\hline \multirow{3}{*}{$\begin{array}{l}\text { Time of the } 3^{\text {rd }} \\
\text { stage of labor } \\
\text { (hr) }\end{array}$} & Group 1 & 50 & 2.18 & 0.745 & 2 & 5 & \multirow{3}{*}{0.014} \\
\hline & Group 2 & 50 & 2.85 & 1.233 & 2 & 6 & \\
\hline & Total & 100 & 2.52 & 1.064 & 2 & 6 & \\
\hline \multirow{3}{*}{$\begin{array}{l}\text { Blood Loss } \\
\quad(\mathrm{ml})\end{array}$} & Group 1 & 50 & 292.20 & 32.780 & 244 & 358 & \multirow{3}{*}{$<0.001$} \\
\hline & Group 2 & 50 & 410.43 & 50.035 & 343 & 486 & \\
\hline & Total & 100 & 351.32 & 72.888 & 244 & 486 & \\
\hline \multirow{3}{*}{$\begin{array}{c}2 \mathrm{hr} \text { Post-labor } \\
\text { Hb\% (mg/dl) }\end{array}$} & Group 1 & 50 & 10.590 & 0.9455 & 9.5 & 12.7 & \multirow{3}{*}{$>0.05$} \\
\hline & Group 2 & 50 & 10.701 & 0.7517 & 9.7 & 12.5 & \\
\hline & Total & 100 & 11.050 & 0.8621 & 9.5 & 12.7 & \\
\hline \multirow{3}{*}{$\begin{array}{c}2 \text { hr Post-labor } \\
\text { HCT }\end{array}$} & Group 1 & 50 & 31.040 & 2.1824 & 28.1 & 36.6 & \multirow{3}{*}{0.021} \\
\hline & Group 2 & 50 & 32.315 & 3.1601 & 26.3 & 38.8 & \\
\hline & Total & 100 & 31.898 & 2.7831 & 26.3 & 38.8 & \\
\hline \multirow{3}{*}{$\begin{array}{c}12 \text { hr Pos- } \\
\text { labor Hb\% } \\
\text { (mg/dl) }\end{array}$} & Group 1 & 50 & 10.510 & 0.9645 & 9.4 & 12.7 & \multirow{3}{*}{$>0.05$} \\
\hline & Group 2 & 50 & 10.640 & 0.744 & 9.5 & 12.3 & \\
\hline & Total & 100 & 10.897 & 0.859 & 9.4 & 12.7 & \\
\hline \multirow{3}{*}{$\begin{array}{l}12 \text { hr Pos- } \\
\text { labor HCT }\end{array}$} & Group 1 & 50 & 31.032 & 2.198 & 28.0 & 36.6 & \multirow{3}{*}{0.022} \\
\hline & Group 2 & 50 & 32.307 & 3.195 & 26.1 & 38.8 & \\
\hline & Total & 100 & 31.822 & 2.8033 & 26.1 & 38.8 & \\
\hline \multirow{3}{*}{$\begin{array}{c}\text { Birth weight } \\
\text { (g) }\end{array}$} & Group 1 & 50 & 3336.67 & 320.004 & 2900 & 3900 & \multirow{3}{*}{$>0.05$} \\
\hline & Group 2 & 50 & 3395.00 & 347.491 & 2800 & 3900 & \\
\hline & Total & 100 & 3365.83 & 332.491 & 2900 & 3900 & \\
\hline
\end{tabular}

$\mathrm{N}$ : number, SD: standard deviation, Min.: minimum, Max.: Maximum, bpm: beat per minute; $\mathrm{Hb} \%$ : Hemoglobin, HCT: hematocrit; hr: hours.

Mann whitney u test

The mean difference in hemoglobin level before and after delivery was $0.38 \pm 0.046$ and $0.57 \pm 0.19$ in group (1) and group (2) respectively with high statistically significant difference between the two groups. As well as, there was a statistically significant difference between the two groups regarding the fall in hematocrit level (Table 4). 
Table (4): Hb\% difference and Hct fall pre- and Post-delivery in both groups.

\begin{tabular}{|c|c|c|c|c|c|c|c|c|c|}
\hline \multirow{4}{*}{ Groups } & \multicolumn{4}{|c|}{ Group (1) } & \multicolumn{4}{c|}{ Group (2) } & P- \\
\cline { 2 - 10 } varacteristics & Min. & Max. & Mean & SD & Min. & Max. & Mean & SD & value \\
\hline Hb difference & 0.1 & 0.4 & 0.38 & 0.046 & 0.1 & 0.2 & 0.57 & 0.19 & $<0.01$ \\
\hline $\begin{array}{c}\text { Hct difference } \\
\text { (HCT fall) }\end{array}$ & 0.1 & 0.2 & 0.168 & 0.05 & 0.1 & 0.3 & 0.290 & 0.07 & 0.02 \\
\hline
\end{tabular}

SD: standard deviation, Min.: minimum, Max.: Maximum, Hb\%: Hemoglobin; HCT: hematocrit. Independent t-test was used

Mann whitney u test

As regarding the history of previous postpartum hemorrhage, there was no statistically significant difference between the two groups.

The different types of side effects that were observed among the studied groups. There was no statistically significant difference between each type of side effects. However, there was a highly significant difference between the total numbers of cases complained from side effects between both groups.

There was no statistically difference between the two groups regarding the need for additional uterotonics (Table 5).

Table (5): History of postpartum hemorrhage, side effects and need for additional uterotonics among the two groups

\begin{tabular}{|c|c|c|c|c|c|c|}
\hline \multicolumn{3}{|c|}{$\begin{array}{ll} & \text { Groups } \\
\end{array}$} & $\begin{array}{c}\text { Group } \\
\text { (1) }\end{array}$ & $\begin{array}{c}\text { Group } \\
\text { (2) }\end{array}$ & Total & $\begin{array}{c}\text { P- } \\
\text { value }\end{array}$ \\
\hline \multirow{4}{*}{$\begin{array}{c}\text { Previous } \\
\text { postpartum } \\
\text { hemorrhage }\end{array}$} & \multirow{2}{*}{ Negative } & Count & 41 & 39 & 80 & \multirow{6}{*}{$>0.05$} \\
\hline & & \% within group & $82 \%$ & $78 \%$ & $80 \%$ & \\
\hline & \multirow{2}{*}{ Positive } & Count & 9 & 11 & 20 & \\
\hline & & \% within group & $18 \%$ & $12 \%$ & $20 \%$ & \\
\hline \multirow{2}{*}{\multicolumn{2}{|c|}{ Total }} & Count & 50 & 50 & 100 & \\
\hline & & \% within group & $100.0 \%$ & $100.0 \%$ & $100 \%$ & \\
\hline \multirow{10}{*}{ } & \multirow{2}{*}{$\begin{array}{c}\text { Facial } \\
\text { flushing }\end{array}$} & Count & 2 & 3 & 5 & \multirow{2}{*}{$>0.05$} \\
\hline & & \% within group & $4 \%$ & $6 \%$ & $5 \%$ & \\
\hline & \multirow{2}{*}{ Headache } & Count & 3 & 8 & 11 & \multirow{2}{*}{$>0.05$} \\
\hline & & \% within group & $6 \%$ & $16 \%$ & $11 \%$ & \\
\hline & \multirow{2}{*}{ Nausea } & Count & 3 & 8 & 11 & \multirow{2}{*}{$>0.05$} \\
\hline & & \% within group & $6 \%$ & $16 \%$ & $11 \%$ & \\
\hline & \multirow{2}{*}{ Shivering } & Count & 2 & 5 & 7 & \multirow{2}{*}{$>0.05$} \\
\hline & & $\%$ within group & $4 \%$ & $10 \%$ & $7 \%$ & \\
\hline & \multirow{2}{*}{ Vomiting } & Count & 2 & 3 & 5 & \multirow{2}{*}{$>0.05$} \\
\hline & & \% within group & $4 \%$ & $6 \%$ & $5 \%$ & \\
\hline \multirow{2}{*}{\multicolumn{2}{|c|}{ Total }} & Count & 12 & 27 & 39 & \multirow{2}{*}{0.0022} \\
\hline & & \% within group & $24 \%$ & $54 \%$ & $39 \%$ & \\
\hline \multirow{4}{*}{$\begin{array}{c}\text { Need for } \\
\text { additional } \\
\text { uterotonics }\end{array}$} & \multirow{2}{*}{ Negative } & Count & 49 & 45 & 94 & \multirow{6}{*}{$>0.05$} \\
\hline & & \% within group & $98 \%$ & $90 \%$ & $94 \%$ & \\
\hline & \multirow{2}{*}{ Positive } & Count & 1 & 5 & 6 & \\
\hline & & \% within group & $2 \%$ & $10 \%$ & $6 \%$ & \\
\hline \multirow{2}{*}{\multicolumn{2}{|c|}{ Total }} & Count & 50 & 50 & 100 & \\
\hline & & \% within group & $100.0 \%$ & $100.0 \%$ & $100 \%$ & \\
\hline
\end{tabular}




\section{DISCUSSION}

As regards the demographic data of the studied patients $(n=100)$, the age ranged from 18 to 39 years. The gestational age ranged from 37 to 41 weeks calculated from the first day of LMP. The gravidity ranged from 1 to 6 . There was no statistically significant difference between the two groups with regard to maternal age, gestational age, gravidity and parity. Regarding BMI, a significant difference was observed between the two groups.

In our study, observation of $\mathrm{Hb} \%$, hematocrit value pre-delivery, 2 hours and 12 hours post-delivery, pulse rate predelivery, blood loss, fetal birth weight and time of $3^{\text {rd }}$ stage among the studied groups revealed that, there was there was a statistically significant difference regarding mean time of third stage, significant difference regarding mean blood loss, and non-significant difference regarding other items.

In the study of Maged et al. (2016), to compare the efficacy of Carbetocin versus oxytocin for prevention of postpartum hemorrhage after vaginal delivery in high risk women, there was no significant difference between the groups in age, gravidity, parity, body mass index, gestational age and fetal birth weight. Risk factors for atonic and traumatic PPH were not significantly different between the groups there was no significant differences between the groups regarding the duration of $1^{\text {st }}, 2^{\text {nd }}$ and 3rd stages of Labor, which was unlike our results. The amount of bleeding, occurrence of $\mathrm{PPH}$, need for other uterotonics, the difference between blood hemoglobin levels before delivery and $24 \mathrm{~h}$ after delivery were significantly lower in the carbetocin group. On the other hand, there was no significant difference between the two groups regarding occurrence of major PPH and the need for blood transfusion, which is agreed with our results. They concluded that, Carbitocin is a better alternative to traditional oxytocin in prevention of PPH after vaginal delivery with minimal hemodynamic changes and similar side effects.

In another study done by Zein El Abdeen (2018), they compared the effect of Carbetocin versus oxytocin and ergometrine for prevention of postpartum hemorrhage following caesarean section, prospective randomized observational study. There were no significant differences between the study groups concerning the age, gravidity, parity, gestational age and BMI. It was found that there was significant association as regards vaginal bleeding between both groups in carbetocin as compared with the mean in oxytocin group was, it was found that uterine atony occurred more in women in the group who received oxytocin with ergometrine $(39 \%)$ in comparison to carbetocin group $(21 \%)$. It was obvious that oxytocin group needed more oxytocics than carbetocin group. This study concluded that uterine atony occurred more in women in the group who received oxytocin with ergometrine (39\%) in comparison to carbetocin group (21\%). It was obvious that oxytocin group needed more oxytocics than carbetocin group. These results were consistent with our results that compared amount of $\mathrm{PPH}$, this study was held on women undergone C.S which was more risky for $\mathrm{PPH}$, and it proved the superior effect of carbetocin above oxytocin combined with ergometrine to prevent $\mathrm{PPH}$. 
Carbetocin is superior to oxytocin in prevention of $\mathrm{PPH}$ and $\mathrm{Hb}$ dropafter vaginal delivery in women with at least two risk factors for developing atonic PPH. This fact can be explained by the known longer half-life of carbetocin when compared to Oxytocin causing a more uterine response, in terms of frequency and amplitude of uterine contraction (Reyes and Gonzalez, 2011).

In our study, there was a statistically significant difference between the two groups regarding $\mathrm{Hb} \%$ difference and $\mathrm{Hct}$ fall pre- and post-delivery in both groups. There was a statistically significant difference between the two groups regarding mean Hct fall.

In the study of Maged et al. (2016), the difference between blood hemoglobin levels before delivery and $24 \mathrm{~h}$ after delivery were significantly lower in the carbetocin group. On the other hand, there was no significant difference between the two groups regarding occurrence of major $\mathrm{PPH}$ and the need for blood transfusion. These results are consistent with our results.

Two substantive studies comparing active management of third stage with expectant management have clearly indicated the advantages of active management. The Bristol trial, in which active management had been the norm, and the Hinchingbrooke trial, in which expectant management had been the norm, both studies demonstrated significant reductions in the incidence of $\mathrm{PPH}$ with active management compared with expectant management $(5.9 \%$ versus $17.9 \%$ and $6.8 \%$ versus $16.5 \%$, respectively). Both studies were terminated after interim analysis because the difference in $\mathrm{PPH}$ rate was so great (Maged et al., 2016).

In the study of Reyes and Gonzalez (2011), they found that carbetocin was more effective than oxytocin in the prevention of PPH. Carbetocin had a safety profile similar to that of oxytocin, and it was not associated with the development of oliguria or hypertension. They concluded that carbetocin is an appropriate alternative to oxytocin for the prevention of PPH in women with severe preeclampsia.

Concerning need for additional uterotonic drugs Authors compared between carbetocin and oxytocin concerning the need for additional uterotonic drugs. They found significant association between both groups. However, when they tested the need for additional uterotonic agents with carbetocin and oxytocin following vaginal deliveries, they found no statistical significance between both groups. This was in agreement with our thesis despite different mode of delivery. Mode of delivery is an important factor that can influence the treatment outcome. Thus, it is recommended to undertake more studies including patients with different modes of delivery and risk factors for PPH (Askar et al., 2011, Westhoff et al. 2013 and Kansouh \& El Naggar, 2019).

In the study of Kansouh and El Naggar (2019), they compared between Carbetocin versus oxytocin in prevention of postpartum hemorrhage in late preterm twin pregnancy following cesarean section. The difference between blood hemoglobin levels $24 \mathrm{~h}$ after delivery was not significantly lower in the carbetocin group. Women in oxytocin group, $2 \mathrm{~h}$ 
after CS, showed a statistically significantly higher SBP and DBP than women in carbetocin group. This study strongly supported our results as was mentioned before twin pregnancy itself is a risk factor for $\mathrm{PPH}$ beside C.S, carbetocin was more effective in preventing PPH than oxytocin.

In our study, there was no statistically significant difference between each type of side effects. However, there was a highly significant difference between the total numbers of cases complained from side effects between both groups. Also there was no statistically difference between the two groups regarding the need for additional uterotonics.

\section{CONCLUSION}

A single $100 \mathrm{mg}$ IM dose of carbetocin $\left(\mathrm{Pabal}{ }^{\circledR}\right)$ may be more effective as compared to 5 IU IM oxytocin (Syntocinon ${ }^{\circledR}$ ) combined with $1 \mathrm{~mL}, 0.2$ mg IM methylergonovine maleate (Methergine ${ }^{\circledR}$ ) in reducing postpartum blood loss with a smaller drop in hemoglobin levels. Carbetocin was combined with the safety of oxytocin with the longer duration of action of ergot preparations.

\section{REFERENCES}

1. Askar AA, Ismail MT, El-Ezz AA and Rabie NH. (2011): Carbetocin versus syntometrine in the management of third stage of labor following vaginal delivery. Archives of Gynecology and Obstetrics, 284(6):135965.

2. Edhi MM, Aslam $H$, Naqvi $Z$ and HashmiH. (2013): Postpartum hemorrhage: causes andmanagement. BMC Research Notes, 6:236-42.
3. El Behery MM, El Sayed GA, Abd El Hameed AA, Soliman BS, Abdelsalam WA and Bahaa A. (2016): Carbetocin versus oxytocin for prevention of postpartum hemorrhage in obese nulliparous women undergoing emergency cesarean delivery. J Matern Fetal Neonatal Med., 29:1257-1260.

4. Grotegut CA, Paglia MJ, Johnson LN, Thames B and James AH. (2011): Oxytocin exposure during labor among women with postpartum hemorrhage secondary to uterine atony. Am J Obstet Gynecol., 204:e51-e56.

5. Kansouh AM and El Naggar MA. (2019): Carbetocin versus oxytocin in prevention of postpartum hemorrhage in late preterm twin pregnancy following cesarean section: a prospective clinical study. Journal of Medicine in Scientific Research, 2(1):54-58.

6. Maged AM, Hassan AM and Shehata NA. (2016): Carbetocin versus oxytocin for prevention ofpostpartum hemorrhage after vaginal delivery inhigh risk women.J Matern Fetal Neonatal Med., 4:532-6.

7. Reyes OA and Gonzalez GM. (2011): Carbetocin versus oxytocin for prevention of postpartum hemorrhage in patients with severe preeclampsia: a double-blind randomized controlled trial. J Obstet Gynaecol Can., 33:1099-104.

8. Su LL, Chong YS, Samuel M. (2012): Carbetocin for preventing postpartum haemorrhage. Cochrane Database Syst Rev., 2: 5457-63.

9. Westhoff G, Cotter AM and Tolosa JE. (2013): Prophylactic oxytocin for the third stage oflabour to prevent postpartum haemorrhage.Cochrane Database of Systematic Reviews, 10: 1808-13.

10. Zein El Abdeen E. (2018): Carbetocin versus oxytocin and ergometrine for prevention of postpartum hemorrhage following caesarean section. Evidence Based Women's Health Journal, 8(1):138-43. 
استخدام الكاربيتوسين مقارنة باستخدام الأكسيتوسين

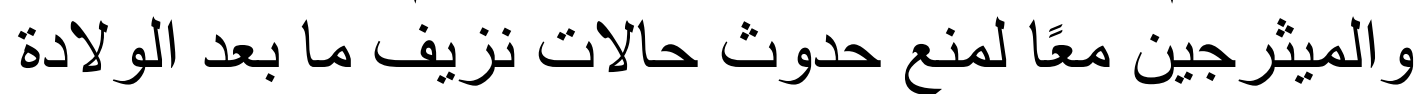
الطبيعية في الحالات عالية الخطورة

محمد جمال نصر الثناوي، محمد محمد جبريل، الرفاعي عبدالفتاح مرعى قسم التوليد و أمراض النساء، كلية الطب القاهرة، جامعة الأزهر

E-mail: mohamedgamal5545@gmail.com

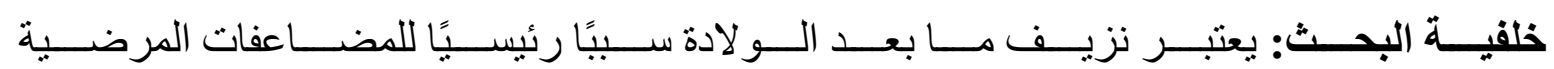

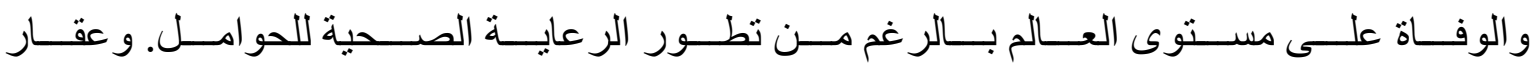

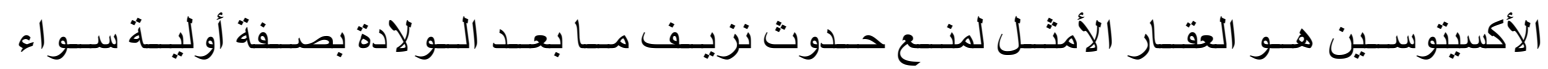



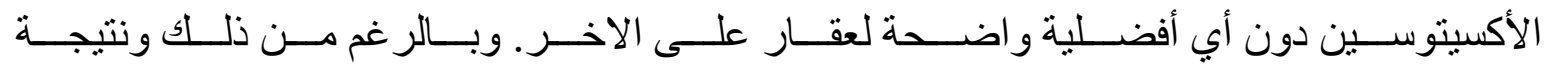

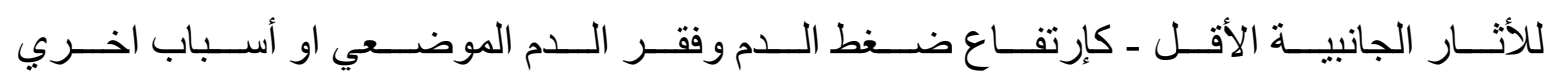

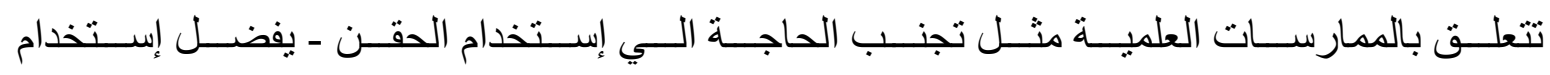

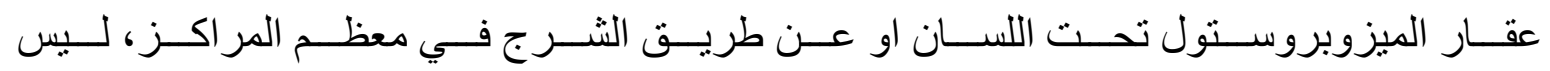

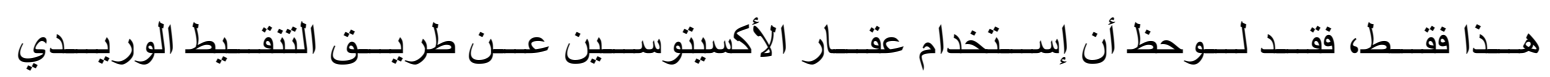
أكثر فعالية في الوقاية من نزيف ما بعد الو لادة وفي وجود حالة نزيف نشطة.

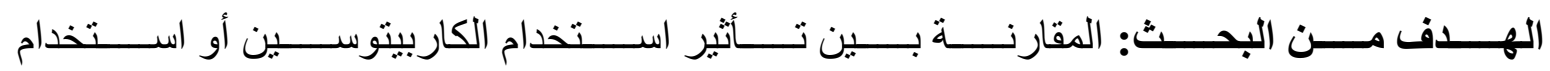

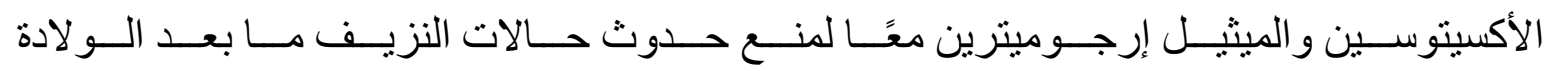
الطبيعية في الحالات عالية الخطورة.

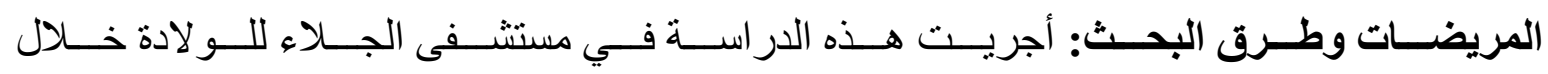

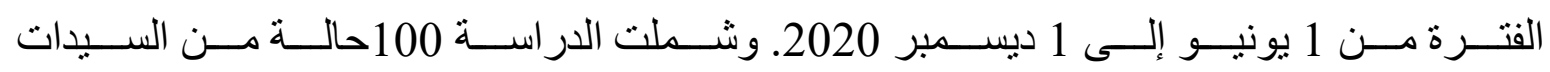

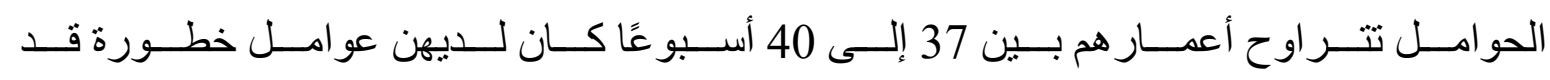

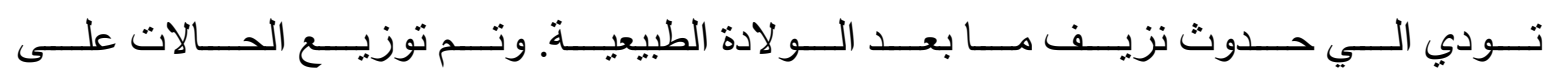

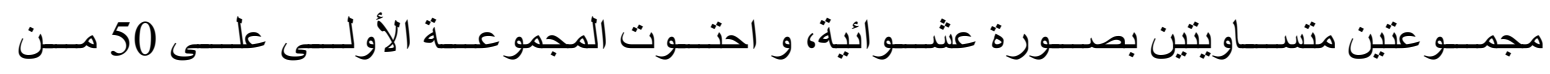

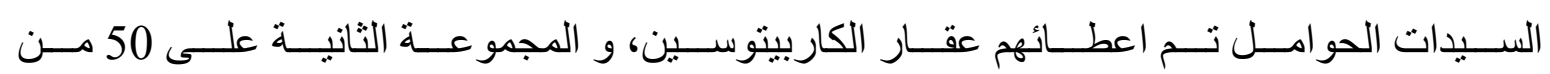
السيدات تم إعطائهن عقاريّ الأكسيتوسين و الميثرجين معًا. 
CARBETOCIN VERSUS COMBINED OXYTOCIN AND METHERGINE... 1087

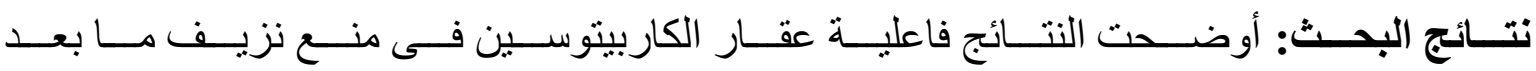

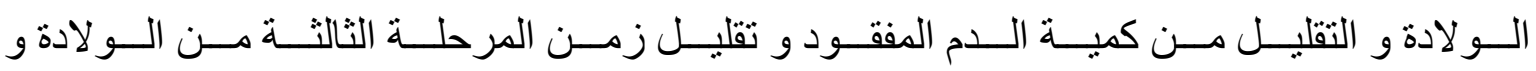

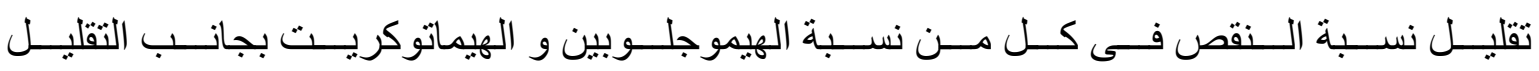
الملحوظ بشدة فى الأعر اض الجانبية المقارنة بالأوكسيتوسين.

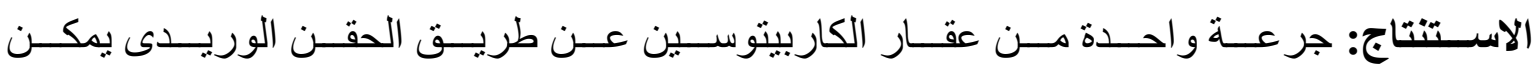

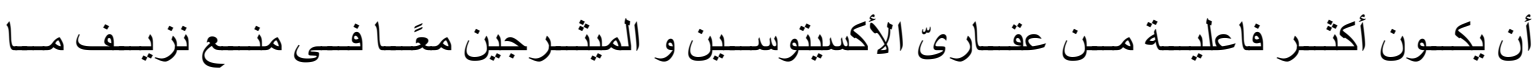

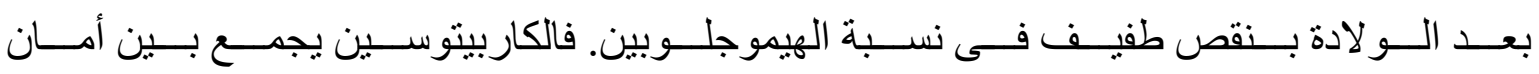

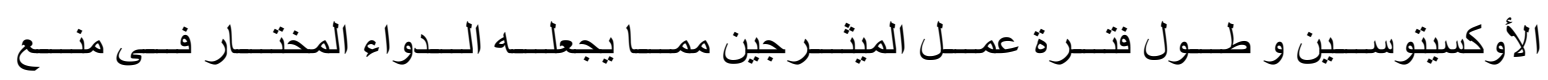
نزيف ما بعد الو لادة.

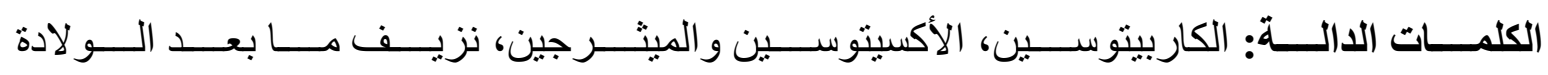
الطبيعبة. 